\title{
MY FATHER ZLATKO KVAČEK
}

I knew this situation would come. And it is here. I am sitting in front of my computer trying to write about my father in the past tense, which is something I am still not used to... Due to our very similar professional interests, I saw him not only as my father, but also as my teacher and my colleague. He gave me a lot, but did not require open expressions of gratitude. He did not hold my hand for everything - he was a man of few words, but was inordinately helpful with those few.

\section{Personal life and education}

Zlatko Kvaček was born on July $28^{\text {th }}, 1937$ in Prague as a second child of my grandfather Jiří, a dentist, and his wife Marie. The family lived in a flat occupying one floor of a house in Praha-Libeň, Primátorská 49. My father liked natural science - this interest was probably inspired by his own grandfather, Josef Kvaček, a school director in Prague and amateur natural scientist. It was Josef who taught Zlatko the basics of botany, and showed him how to prepare his first herbarium. Zlatko assembled his first plant collection near Žd'ár nad Sázavou, in the village of Velká Losenice, where his own father was born in 1904.

After primary school, where his best friend was Milan Valouch, who later tragically died as a climber in Vysoké Tatry, Zlatko attended high school (gymnasium in Czech) in Praha-Libeň. There he met his life-long friend Pavel Veselý, now a medical doctor in Prague. Pavel was interested in herpetology, Zlatko in botany, so they joined forces for numerous field trips, mostly to Slovakia (Text-fig. 1). One of those, the expedition to Latorica river, was a pioneering Czech-Slovak scientific expedition, led by Dr. Hanzák, Dr. Kalaš and Dr. Tř́ska, all from the National Museum. For all his life, Zlatko was an avid photographer, so from as early as his high school days, there are many high-quality photographs in his photo-albums.

In 1958, after finishing high school, Zlatko continued his studies at the Faculty of Sciences of Charles University in Prague (Text-fig. 2). There he met number of his later colleagues, among them František Holý and Milada (Midla) Vavrdová (née Dvořáková), and became a student of Professor František Němejc, a renowned Czech palaeobotanist. He graduated under Professor Němejc's supervision with a diploma thesis titled, "Tertiary plant remains from the Julius Fučík Mine, in Želénky near Duchcov".

While still in high school, during a dance course, my father met my mother Hana, and their relationship was cemented by a wedding on July $7^{\text {th }}, 1961$. The marriage gave them two children: Jiř́ (myself) and my sister Lucie.

\section{Early professional life}

From 1961 to fall of 1962, Zlatko was employed as a geologist by the mining institute Geologický průzkum n.p. Dubí, branch doprovodné suroviny - non-coal resources.

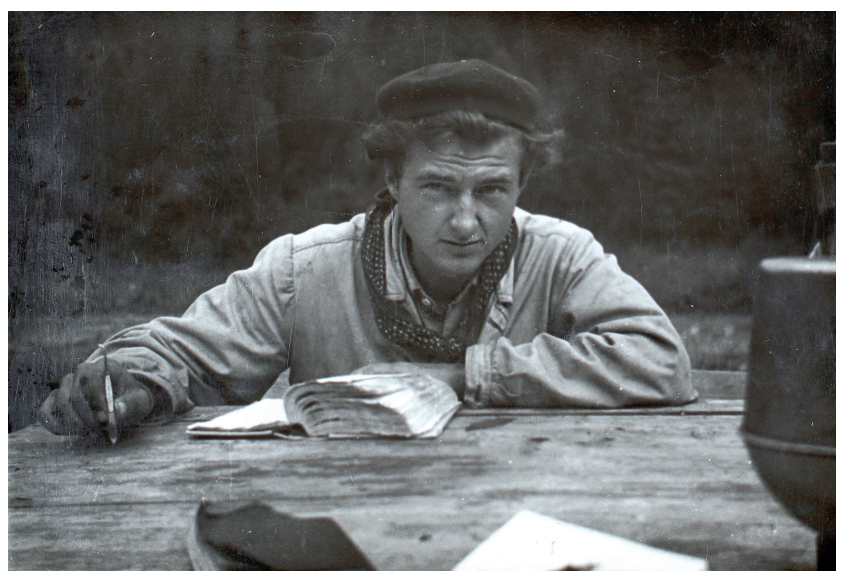

Text-fig. 1. Zlatko Kvaček in Belanské Tatry identifying plants using his field-trip botanical key. Photo Pavel Veselý, 1954.

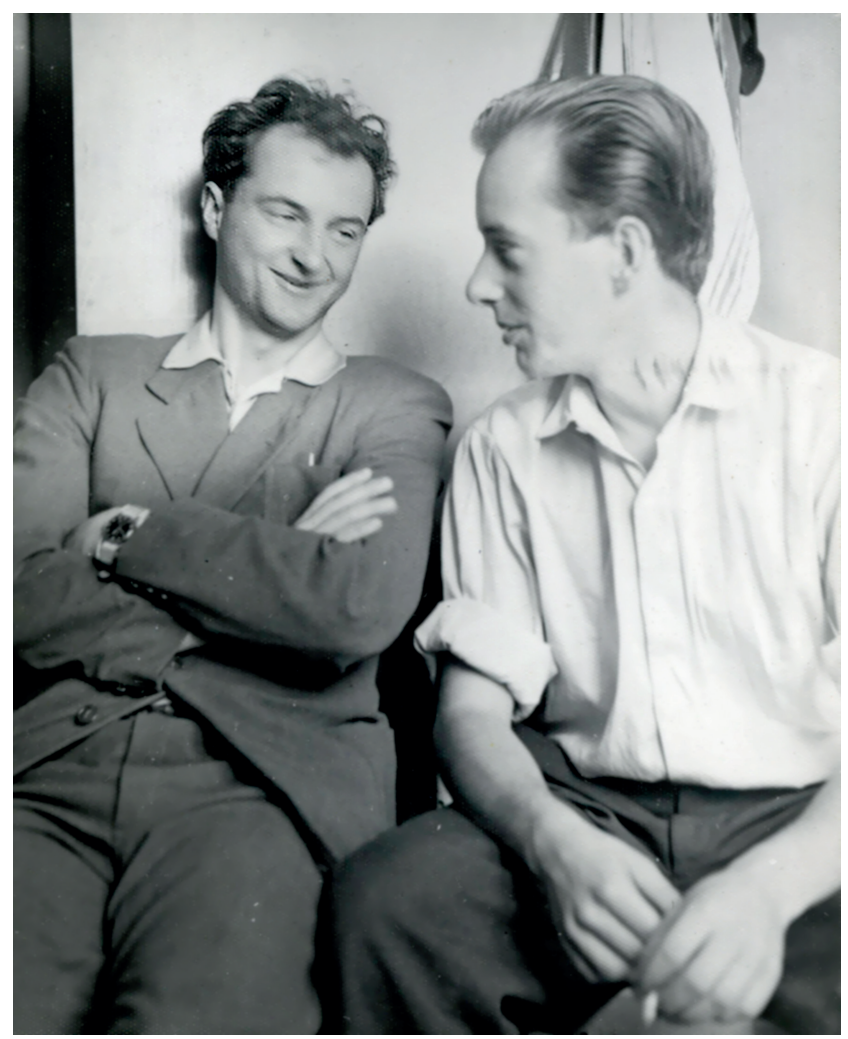

Text-fig. 2. Zlatko Kvaček with his schoolmate and friend Jan Ptáčník. Photo Anonymous, 1958. Beginning October 1 $1^{\text {st }}, 1962$, he left the mining institute and started to work as a scientific assistant under Dr. Pavel Čepek in the Geological Institute of the Czechoslovak Academy of Sciences. During that time, he also began his PhD study in the same institute, but under the supervision of Professor Němejc, with the topic, "Evolution of brown coal swamp flora in Bohemia during the late Tertiary". He successfully defended the thesis in 1966, and received the title CSc. (socialist equivalent of $\mathrm{PhD}$.) on May $17^{\text {th }}, 1966$. He regularly reported his investigations in conferences (Text-fig. 3). From summer 1966 to spring 1967, he was sent to the Birbal Sahni Institute in Lucknow on a research 


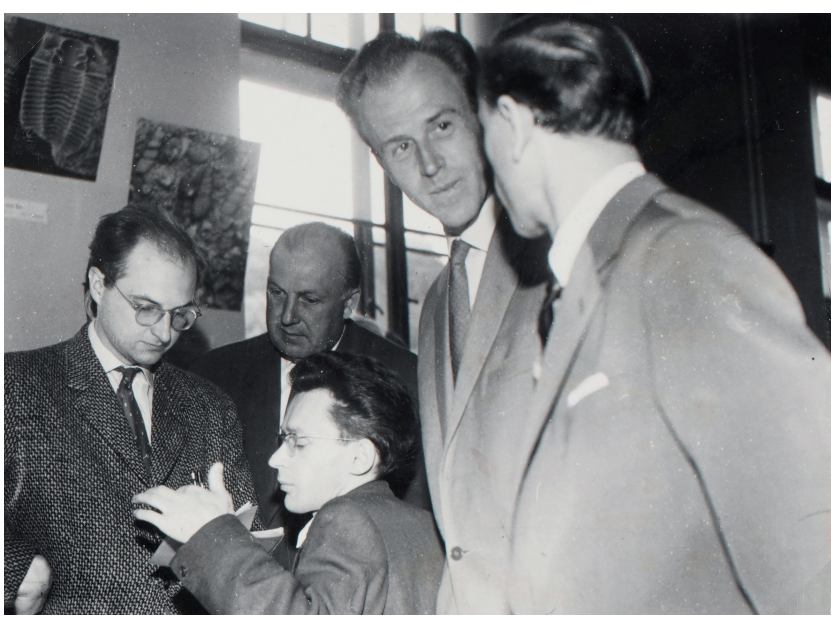

Tet-fig. 3. Zlatko Kvaček during palaeontological conference. From left Zlatko, Čestmír Bůžek, Zdeněk Špinar, Vladimír Pokorný, Radomír Čihák. Photo Anonymus, 1964.

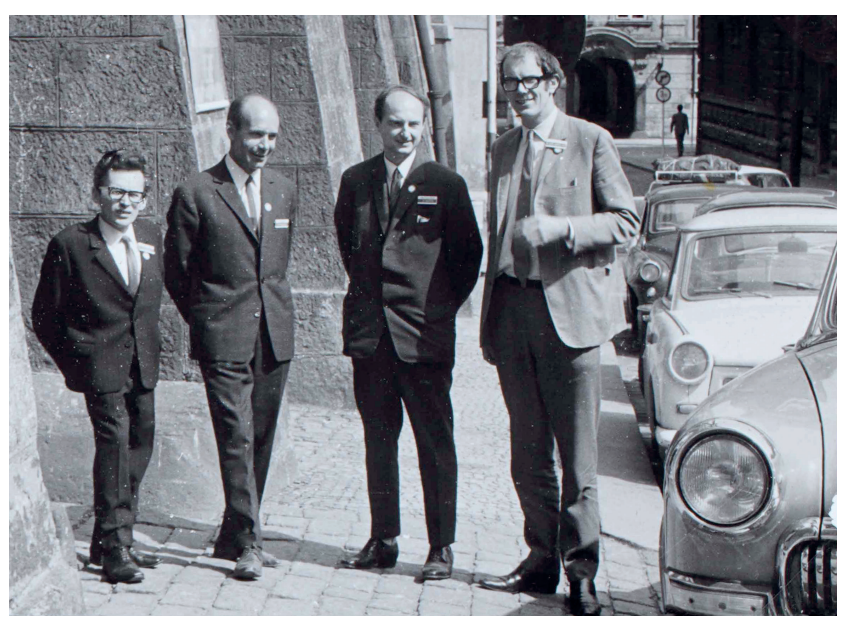

Text-fig. 4. Zlatko Kvaček with his colleagues. From left: Čestmír Bủžek, Razvan Givulescu (Romania), and Mike Boulter (United Kingdom) during the International Geological Congress in Prague. Photo Anonymous, August 1968.

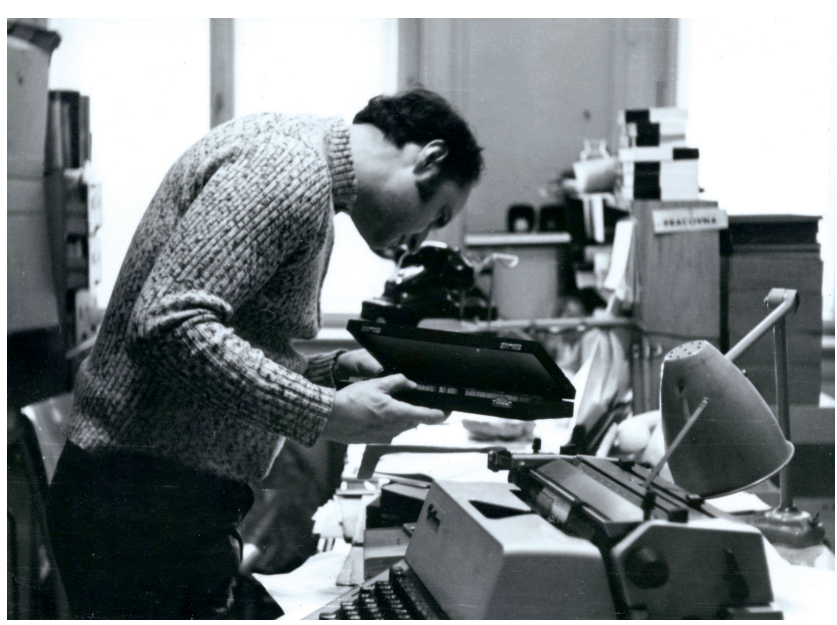

Text-fig. 5. Zlatko Kvaček in his office in Spálená 49. Photo Anonymous, 1973. fellowship, together with Midla Vavrdová, a co-worker at the institute. There he studied Indian Tertiary floras (Kvaček 1969). He assembled a large herbarium of modern plants, which he used for comparison in his later palaeobotanical studies. On December $8^{\text {th }}, 1967$, he completed exams for the scientific title RNDr. at Charles University in Prague.

Throughout these years, Zlatko took part in collaborations with Čestmír Bůžek, František Holý and Ervín Knobloch, all also students of Professor Němejc. They worked jointly on Bohemian and Moravian Tertiary floras. Bůžek and Holý focused mostly on carpology, Knobloch on macroremains, Zlatko on cuticle analysis. In the late 1960s, he also collaborated with his German colleagues, particularly with Harald Walther. Harald eventually became a frequent guest in the weekend cottage my parents bought in 1978. He knew bricklaying, and helped us rebuild the cottage, often spending holidays there with us.

Another long-term friend and colleague was Mike Boulter from London, whom Zlatko met in 1968, during the International Geological Congress in Prague (Text-fig. 4). Unfortunately, the congress was forced to an abrupt and unexpected end by the arrival of Russian and other occupational troops, who invaded Prague in August 1968. However, M. Boulter was able to subsequently visit Prague, collaborating with Zlatko on projects like the Palaeoclimate of Tertiary floras (Boulter and Kvaček 1989). A number of my father's foreign colleagues stayed at our house instead of a hotel. It was a cheaper and more secure solution, because before 1989, it was not easy with visitors from the other side of the Iron Curtain.

August $1^{\text {st }}, 1973$, Zlatko was appointed head of the palaeontology department in the Geological Institute, whose palaeobotany section was housed in Spálená 49, Praha 1 (Text-fig. 5). There he met Antonín Hluštík and became his supervisor. Hluštík defended his thesis on Cretaceous conifers, family Frenelopsidaceae in 1983, as my father's first $\mathrm{PhD}$. student. Also in 1983, the Geological Institute's palaeobotany laboratory had to move from Spálená to Praha-Lysolaje, Rozvojová street, where the institute had acquired a provisional building. It was a good deal of work for Zlatko to transfer all the institute's collections from the old provisional depots to the new building - there was a lot of material. The new building, although provisional, contained modern laboratory facilities, providing much more suitable conditions for storage and research. In 1987, Zlatko successfully defended his Doctor of Science thesis "Cuticle analysis of Neogene trees from Central Europe" in the Czechoslovak Academy of Sciences, while still working in the Geological Institute, and December $9^{\text {th }}, 1987$, he received the title DrSc.

\section{Conferences, research, and field work}

Prof. Blanka Pacltová ofCharles University and Professor Němejc initiated the idea to organize an international conference on angiosperm palaeobotany in Prague, when

Professor Němejc died, in 1976. Zlatko fully took over organizing the conference, titled "Advances in Angiosperm Palaeobotany", which took place in 1977, in the Liblice castle in Central Bohemia. The conference was a rare opportunity to meet colleagues from both sides of the Iron Curtain (Text-figs 6,7). International conferences were supported in the country because they were viewed by the communist establishment as showing freedom and support of science. Many renowned palaeobotanists of that time came 


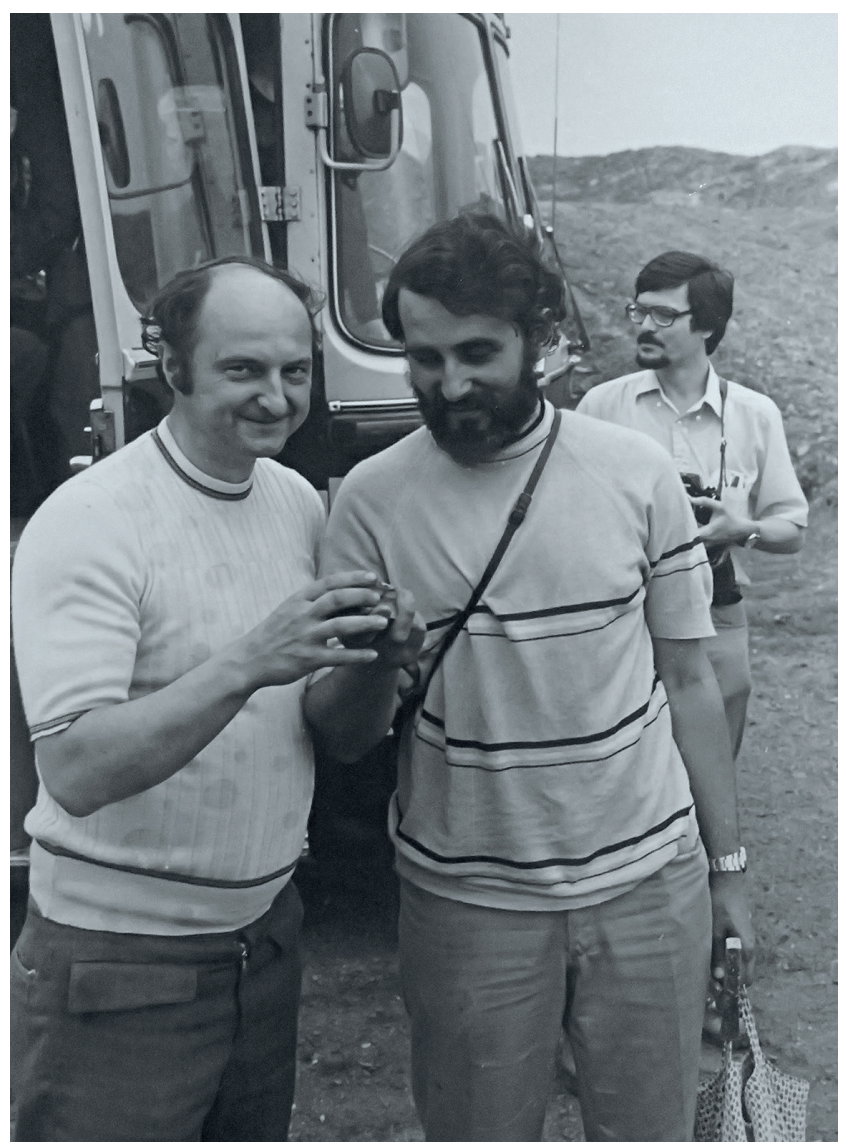

Text-fig. 6. Zlatko Kvaček and František Holý during the field-trip to Maxim Gorkij Mine, with James Doyle, North Bohemia, International Conference Advances in Angiosperm Palaeobotany. Photo Anonymous, 1977.

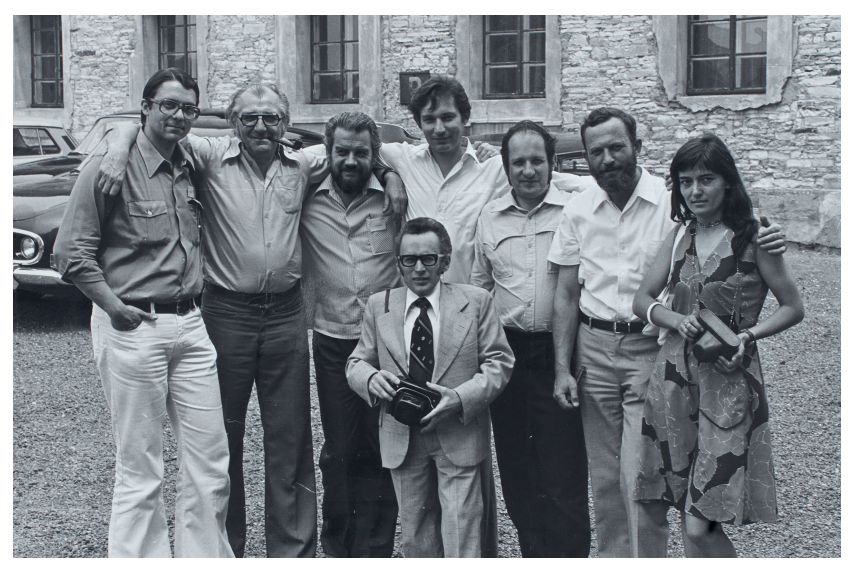

Text-fig. 7. Group photo of Tertiary palaeobotanists attending the International Conference Advances in Angiosperm Palaeobotany in Liblice. From left to right, back row: Jochen Gregor (Germany), Harald Walther (Germany), Leon Stuchlik (Poland), Walter L. Friedrich (Germany), Dieter H. Mai (Germany), Martin Sturm (Germany), Lilla Hably (Hungary), front: Čestmír Bůžek. Photo Zlatko Kvaček 1977.

to this one, including David Dilcher, Norman Hughes and Gerhard Kremp. Peter Crane came as a young beginning $\mathrm{PhD}$ student from the UK. There were additional colleagues from USA (James Doyle and Leo Hickey), West Germany (Joachim Gregor, Friedman Schaarschmidt), East Germany (Harald Walther, Dieter Mai), Poland (Leon Stuchlik, Ewa Zastavniak), Hungary (Lilla Hably) and others, in total from thirteen countries.

After the conference, Zlatko started his long-lasting collaboration with Zdeněk Dvořák from the brown coal mine Maxim Gorkij, later renamed Bílina. Together with

Čestmír Bůžek, Zlatko made a number of field trips to this mine, visiting Zdeněk Dvořák and his co-workers. After Bůžek’s death in 1991, Jakub Sakala joined Zlatko and Z. Dvořák; they expanded this work, and prepared a photo atlas of Tertiary fossil plants, unconventionally written in Czech (Kvaček et al. 2004). This publication was so well received that a second edition was printed, with many new additions (Kvaček et al. 2019).

His collaboration with Harald Walther started in the 1960s, intensified in the 1970s, and this intense work persisted until Harald Walther passed away in 2013. Besides their professional association, Harald and Zlatko were also close personal friends, as mentioned earlier. With Harald, Ervín Knobloch and Dieter Mai, they organized regular social gatherings with their wives to celebrate birthdays, generally alternating between Germany and Prague (Text-fig. 9).

In the late 1970s, he began his collaboration with Lilla Hably from Budapest (text-fig. 8). They collaborated on numerous Hungarian floras; at Lilla's invitation, he travelled many times to Budapest for both field trips and to the museum, and they worked together on numerous joint projects. Lilla eventually became head of the botany department in the Natural History Museum in Budapest (nowadays Hungarian Natural History Museum).

Slightly later, in 1980, Zlatko met Johanna Kovar (later Kovar-Eder), and taught her cuticle analysis. She later became one of his principal professional associates (Text-fig. 10); they collaborated on various projects, primarily on Austrian floras, one of which was a revision of Ettingshausen material from Parschlug (Kovar-Eder et al. 2004). These collaborative projects continued throughout both their careers, despite Johanna's additional administrative duties beginning in 2003, when she was named director of the Staatliches Museum für Naturkunde, Stuttgart.

Together with Ervín Knobloch, Zlatko organized a palaeobotanical conference in September 1989, titled "Palaeofloristic and palaeoclimatic changes in the Cretaceous and Tertiary", in which numerous renowned palaeobotanists took part, including Steven Manchester from the University of Florida, USA. Steven and Zlatko had already known each other via mail correspondence, based on scientific letter exchange and work on Pteleaecarpum. After the conference, they agreed on longer exchange visits, and Steven subsequently became his frequent collaborator and personal friend. Zlatko visited Florida, from where Steven also took him on trips to US fossil sites and museums. When Steven visited Prague (Text-fig. 11), Zlatko did the same for him around Europe. Zlatko also introduced Steven to many other European researchers and facilities.

At the 2002 European Palaeobotany-Palynology Conference in Greece, I suggested to my father that we could organize the next European Palaeobotany-Palynology Conference in Prague, for the 2006 session. Our offer to host the 2006 conference was accepted by the Conference Committee, and Zlatko became the principal organizer. His outstanding professional reputation was a key factor in attracting so many talented scientists, who jointly made the conference a success. More than 400 participants 


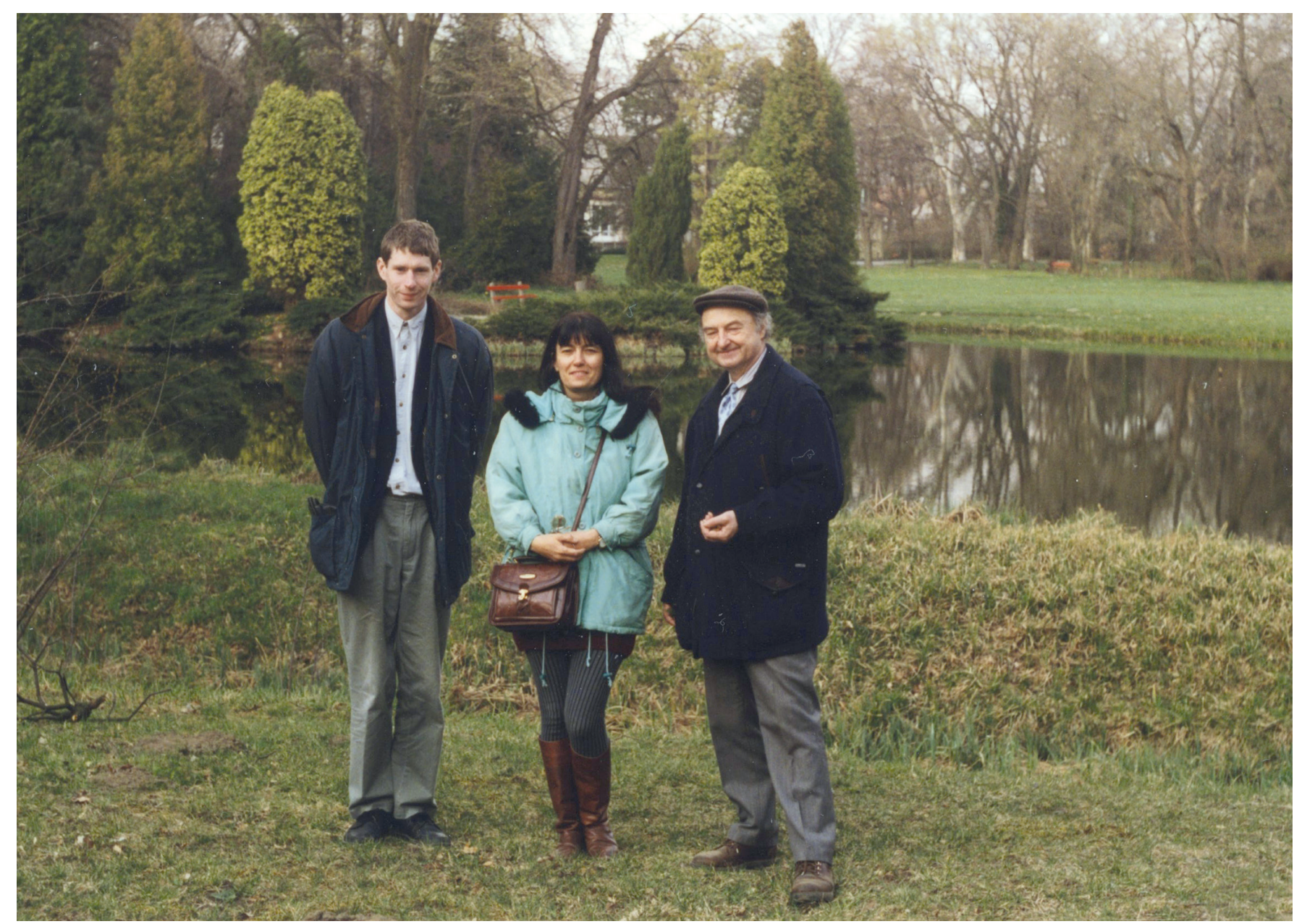

Text-fig. 8 Zlatko Kvaček with Lilla Hably and Fred Titchener (student from Royal Holloway College, London) in Vácrátót Botanical Garden, Hungary. Photo György Szakmány, 1997.

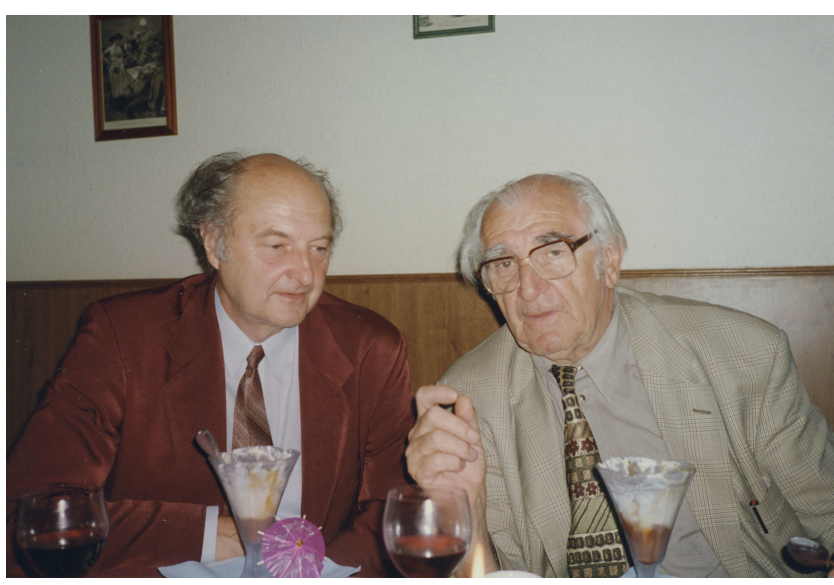

Text-fig. 9. Zlatko Kvaček and Harald Walther during celebration of Zlatko's $6^{\text {th }}$ birthday in Troja castle restaurant, Prague. Photo Ervín Knobloch, 1997.

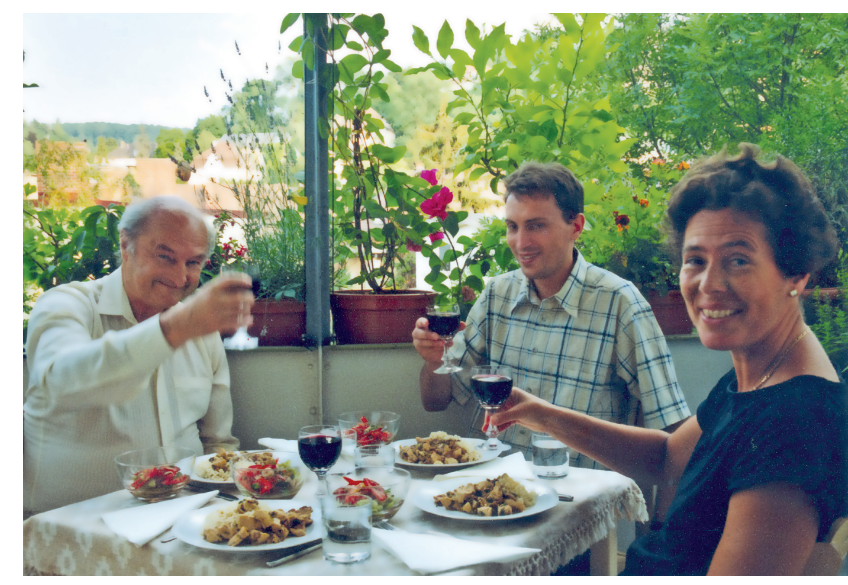

Text-fig. 10. Zlatko Kvaček with Johanna Eder-Kovar (Austria) and Ivan Gabryelian (Armenia) visiting Stuttgart in 2003. Photo Helmut Sommer, 2003.

came to Prague, from all over the world, presenting their contributions in five parallel sections. Successful organization was the highlight of his administrative activity in palaeobotany.

\section{At the university}

After the Velvet Revolution in November 1989, Professor Blanka Pacltová asked Zlatko (along with other noteworthy palaeontologists) to teach at Charles University. November $11^{\text {th }}, 1991$, he became an associate professor there; December $15^{\text {th }}$, 1998, a full professor. As a member of the faculty, Zlatko focused on recruitment and education of students. His regular students were Jakub Sakala, Vasilis Teodoridis, Josef Pšenička, Milan Libertín, Helena Soukupová, Jana Zajícová, but he supported many 
others, among them Jakub Prokop and Jiřina Dašková. All of them successfully defended their theses and received their degrees under his formal or informal supervision. I also attended his lectures, together with Jiří Bek and Jana Drábková. Eventually, some his lectures were attended by almost the entire current staff of the palaeontological department of the National Museum, as well as other Czech palaeontological and geological institutions. My father retired in 2003, but he remained employed in the faculty until 2018, when he was made professor emeritus (April 1 $\left.{ }^{\text {st }}, 2018\right)$.

During his tenure at the university, there were other colleagues outside the school with whom Zlatko coworked. He conducted research and published with Dieter Hans Mai, Volker Wilde, Thomas Denk, Lutz Kunzmann and Heinrich Winterscheid on primarily German Tertiary floras, Evangelos Velitzelos on Tertiary floras of Greece, Leon Stuchlik, Ewa Zastawniak, Grzegorz and Elzbieta Worobiec on primarily Polish Tertiary floras, Edoardo Martinetto on Italian Neogene floras, Svein B. Manum on Paleogene flora of Spitzbergen, William Rember on Tertiary floras of USA, Wolfram Kürschner on plant palaeoecology, Mikhail Akhmetiev on volcanic floras, Josef Bogner on fossil Araceae, and Jan J. Wojcicki on Trapaceae. Beside Tertiary floras, Zlatko was involved also in investigations of Cretaceous plants, particularly leaves of angiosperms (Kvaček 1983), and Paleozoic biota (Kenrick et al. 1999).

\section{Autumn}

In 2007, the National Museum hosted a conference dedicated to Zlatko's seventieth birthday, titled "Palaeobotany - contributions to the evolution of plants and vegetation". This was an occasion for a number of "old friends" to meet again (Text-fig. 12). Towards the end of his career at the university, after the National Museum opened its new depositors in 2011, I took my father there nearly every Friday. Right away, he helped me systematically arrange the museum's collection of Tertiary plants, which was in a rather chaotic state after decades of cramped storage in the basement of the museums historic building, and subsequent harried transport to the new depositories. When that was completed, he continued his palaeobotanical research there, using the museum's collections, microscopes, computers and library, and assisted the museum's curators with identification of fossils. The museum's palaeontological department also provided excellent opportunities to encounter professional colleagues (Text-fig. 13). In 2017, another dedicated conference took place at the Faculty of Science of Charles University, for his eightieth birthday.

In the last decades of his life, Zlatko intensely collaborated with his earlier student Vasilis Teodoridis from the Pedagogic Faculty of Charles University. It was primarily Vasilis who helped Zlatko to maintain an interest in his work and recover from his difficulties with walking, caused by contracting Lyme disease in 2011. In summers, my father and mother spent their time in a cottage in Horka u Staré Paky. They were often visited by other members of the family, including grandchildren, and non-family friends, e.g., Jakub Sakala and his wife, who came to socialize and helped with gardening.

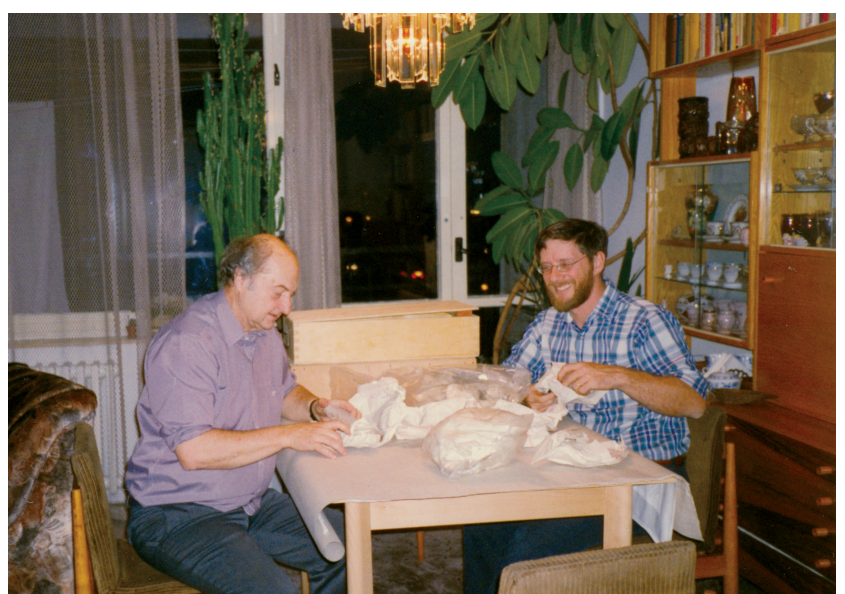

Text-fig. 11. Zlatko at home in Praha 8 - Čimice, Okořská 340 with Steven Manchester. Photo Hana Kvačková, 1997.

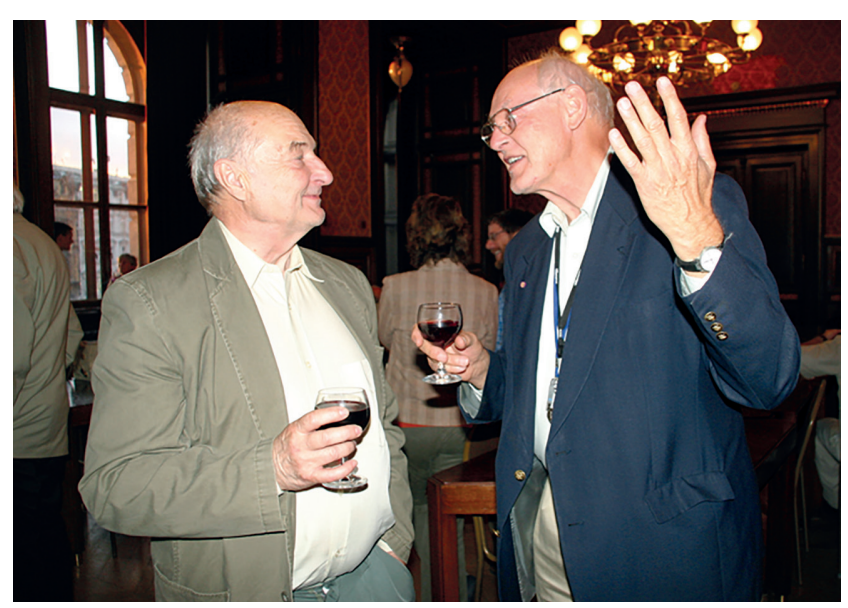

Text-fig. 12. Zlatko Kvaček with David Dilcher (USA) during welcome party at the conference Palaeobotany - contributions to the evolution of plants and vegetation: (recognizing the contribution of Zlatko Kvaček on the occasion of his $7^{\text {th }}$ birthday) in the National Museum, Prague. Photo Jiřina Dašková, 2007.

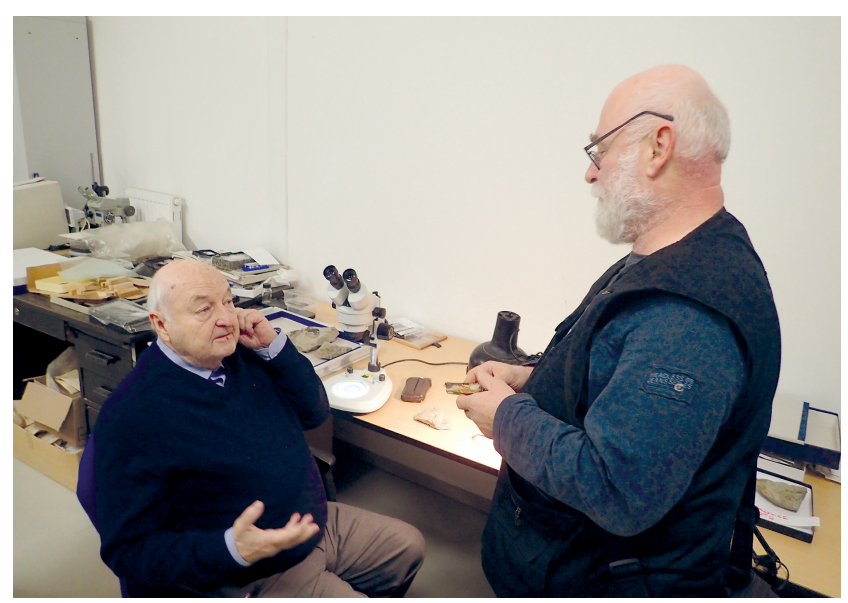

Text-fig. 13. Zlatko Kvaček with Zdeněk Dvořák on December $6^{\text {th }}, 2019$ in the depository of the Department of Palaeontology, National Museum. This was their last meeting. Photo Jiří Kvaček, 2019. 
In the summer of 2020, Zlatko vacated his office in Charles University and moved all his professional gear to the National Museum depository facility, assuming the position of researcher emeritus, planning to make use of the easier access to the museum's collections. The staff was excited to have their former professor so near at hand, but sadly, in the fall of 2020 , he contracted Covid-19, and died within a matter of weeks.

\section{Farewell}

I conclude this short text with some numbers. Professor Zlatko Kvaček was a prolific writer, authoring and co-authoring fifteen books and monographs and nearly 300 papers. He supervised six graduate students and six PhD. students, and was a mentor to many others. He is a model for all of us with his tireless work in scientific and organizational activity. All honour to his memory.

\section{Acknowledgements}

I am grateful to Michael Boulter, Peter Crane, Lilla Hably, Johanna Kovar-Eder, Hana Kvačková, Steven Manchester, Mihai Popa and Pavel Veselý for providing me information to specify details of the above text. I am also grateful to Petr Daneš who assisted me in writing the text in correct English.

\section{References}

Boulter, M. C., Kvaček, Z. (1989): The Palaeocene flora of the Isle of Mull. - Special Papers in Palaeontology, 42: 1-149.

Kenrick, P., Kvaček, Z., Bengtson, S. (1999): Semblant land plants from the Middle Ordovician of the Prague Basin reinterpreted as animals. - Palaeontology, 42: 991-1002.

Kvaček, Z. (1969): Hlavní směry výzkumu třetihorních květen v Indii [Principal directions in research of Tertiary floras in India]. - Časopis pro mineralogii a geologii, 14: 115-117.

Kvaček, Z. (1983): Cuticular studies in angiosperms of the Bohemian Cenomanian. - Acta Palaeontologica Polonica, 28: 159170.

Kvaček, Z., Dvořák, Z., Mach, K., Sakala, J. (2004): Třetihorní rostliny severočeské hnědouhelné pánve [Tertiary plants of North Bohemian Brown Coal Basin]. - Severočeské doly, a. s., Chomutov, Granit, Praha, 160 pp.

Kvaček, Z., Dvořák, Z., Mach, K., Sakala, J. (2019): Třetihorní rostliny severočeské hnědouhelné pánve (druhé rozšířené vydání) [Tertiary plants of North Bohemian Brown Coal Basin, second extended edition]. - Bílinská přírodovědná společnost z.s., Bílina, Granit, Praha, 191 pp.

Jiří Kvaček, Prague 